STUDIA EDUKACYJNE NR 31/2014

\author{
JAN STRUGAREK \\ Uniwersytet im. Adama Mickiewicza \\ $w$ Poznaniu
}

\title{
POTENCJALNE MOŻLIWOŚCI WYKORZYSTANIA INTERAKTYWNYCH GIER RUCHOWYCH W KORYGOWANIU WAD POSTAWY U DZIECI
}

\begin{abstract}
Strugarek Jan, Potencjalne możliwości wykorzystania interaktywnych gier ruchowych w korygowaniu wad postawy u dzieci [The Potential of Using Exergames for Correcting Posture Problems of Children]. Studia Edukacyjne nr 31, 2014, Poznań 2014, pp. 289-304. Adam Mickiewicz University Press. ISBN 978-83-232-2781-6. ISSN 1233-6688

In Poland we observe a large scale of posture deformations and consequent health implications in the population of school children. Therefore many pedagogical and medical societies are looking for ways and methods of preventing and reversing this negative trend. The purpose of this article is to present the potential of practical use of new posture correction interactive games among school children. Some of the newest equipment and ways of detecting and registering natural human movement have been presented. Teletransmision of data in real time makes it possible for a physiotherapist to supervise and modify the player's motor behavior. Creating visually attractive and involving forms of physical exercise might help encourage and inspire children to reject a sedentary lifestyle.
\end{abstract}

Key words: exergames, posture problems, posture correction

Coraz powszechniejsze występowanie wad postawy u dzieci i młodzieży staje się jednym $\mathrm{z}$ najpoważniejszych zagrożeń dla ogólnego poziomu zdrowotności naszej populacji. Wielu współczesnych naukowców - lekarzy, kinezyterapeutów, czy nauczycieli - realizuje szereg projektów badawczych mających na celu uświadomienie obywatelom skali problemu, a także znalezienie sposobów i metod przeciwdziałania oraz odwrócenia tych niekorzystnych tendencji.

\section{Wady postawy i ich implikacje zdrowotne}

Postawa ciała w okresie dzieciństwa i adolescencji kształtuje się pod wpływem czynników natury morfologicznej, funkcjonalnej i środowiskowej, 
a jej fizycznym przejawem jest osiągnięcie specyficznego, osobniczego nawyku ruchowego. Jego kształt i trwałość uzależniona jest od określonego stanu psychofizycznego organizmu. Postawa jest więc, jak podają Zwierzchowska i Gawlik „(...) wskaźnikiem mechanicznej wydolności zmysłu kinetycznego, równowagi mięśniowej i koordynacji nerwowo-mięśniowej" 1 . Według Kasperczyka, jest to ,„(...) indywidualne ukształtowanie ciała i położenie poszczególnych odcinków tułowia oraz nóg w pozycji stojącej”2 2 . Wpływ na kształt postawy mają czynniki związane z wiekiem, płcią rasą, typem somatycznym, czy uwarunkowaniami środowiskowymi, a w związku z tym przyjęcie jednego, uniwersalnego dla wszystkich wzorca jest niemożliwe. Duże zróżnicowanie i złożoność kryteriów oceny spowodowały, że $\mathrm{w}$ literaturze pojawia się wiele technik i sposobów oceny postawy ciała w kontekście jej wpływu na właściwe i kompleksowe funkcjonowanie organizmu. Jej prawidłowość warunkuje właściwa lokalizacja elementów ruchomych ciała (głowy, klatki piersiowej, miednicy, kończyn) względem kręgosłupa oraz względem siebie. Ukształtowanie kręgosłupa (prawidłowych jego krzywizn) w procesie ontogenezy musi zapewniać spełnianie przez ten organ jego trzech zasadniczych funkcji - podporowej, kinetycznej i amortyzacyjnej. Połączenia ruchomych części szkieletu, stawy nie mogą z kolei ograniczać ich anatomicznych zakresów ruchomości. Odpowiednia wydolność i sprawność układu kostno-stawowego zależy natomiast również od właściwie rozwiniętego układu mięśni szkieletowych. Kwalifikacja określonej postawy uzależniona jest więc od aktualnego obrazu kości, ich połączeń oraz wszystkich mięśni odpowiedzialnych za prawidłową kinetykę ciała.

Zdiagnozowane zaburzenia czy wady postawy prowadzą do powstania pewnych dysfunkcji w obrębie aparatu kostno-stawowo-mięśniowego. Można je podzielić na proste - zwane również błędami postawy, obejmujące pojedyncze anomalie rozwojowe aparatu ruchu, za wyjątkiem kręgosłupa oraz wady złożone, w których mamy do czynienia z deformacjami kręgosłupa. Według kryterium przyczynowego, najczęściej pojawiającego się $\mathrm{w}$ literaturze, wady postawy dzielimy na wrodzone (powstające $\mathrm{w}$ układzie kostnym bądź mięśniowym) oraz nabyte (będące skutkiem jednostki chorobowej lub szerokiego spektrum czynników środowiskowych).

W pierwszych latach życia zmiany postawy ciała przebiegają wolno, tym niemniej jest to okres kształtowania się odpowiednich nawyków ruchowych.

${ }^{1}$ A. Zwierzchowska, K. Gawlik, Korektywa dzieci i młodzieży z dysfunkcjami wzroku lub stuchu, Katowice 2006, s. 71.

2 T. Kasperczyk, Wady postawy ciała. Diagnostyka i leczenie, Kraków 1994, s. 9. 
W badaniach Maciałczyk-Paprockiej i współautorów ${ }^{3}$, przeprowadzonych na próbie dzieci przedszkolnych (3-6 lat) oraz Czernickiego i współautorów ${ }^{4}$, przeprowadzonych na próbie dzieci 4-5-letnich, stwierdzono u ponad $80 \%$ z nich różnego typu wady postawy, przy czym najczęściej dotyczyły one stóp, barków i kolan. Innym istotnym wnioskiem tych badań jest stwierdzenie zwiększania się wraz z wiekiem ograniczenia ruchomości w stawach. Niepokojący fakt stanowi również zwiększanie się ilości wad postawy wraz z wiekiem.

Według Kutzner-Kozińskiej ${ }^{5}$, najbardziej krytyczne w kontekście wystąpienia wad postawy są dwa okresy obejmujące czas edukacji szkolnej. Pierwszy, występujący na samym początku nauki szkolnej (6-7 lat), wiąże się z drastyczną zmianą trybu życia i przejściem z etapu swobodnych zabaw z wieloma elementami ruchu do obowiązku kilkugodzinnego przebywania $\mathrm{w}$ pozycji siedzącej, wielokrotnie w niedostosowanych do wieku uczniów ławkach szkolnych. Drugi, zbiegający się z okresem pokwitaniowym, związany jest $\mathrm{z}$ gwałtownym wzrostem wysokości ciała i przyrostem długości kończyn.

\section{Statystyki występowania odchyleń od prawidłowej postawy u dzieci i młodzieży oraz główne źródła powstawania nabytych wad postawy}

Wyniki badań przeprowadzonych w obu grupach wiekowych, w zależności od regionu kraju są zróżnicowane. Odsetek dzieci i młodzieży ze stwierdzonymi wadami postawy w przedziale wiekowym 7-15 lat jest zastraszający i waha się od $65 \%^{6}$ do ponad $90 \%^{7}$ badanych populacji. Wyniki te, $\mathrm{w}$ zestawieniu choćby $\mathrm{z}$ rezultatami badań wad postawy dzieci $\mathrm{w}$ wieku szkolnym przeprowadzonych w Republice Czeskiej, są wysoce niepokojące.

${ }^{3}$ K. Maciałczyk-Paprocka i in., Postawa ciała dzieci w wieku przedszkolnym, Problemy Higieny i Epidemiologii, 2011, 92 (2), s. 286-290.

${ }^{4} \mathrm{~K}$. Czernicki i in., Częstość występowania wad postawy u dzieci w wieku 4-5 lat uczęszczających do przedszkoli w Mystowicach, Annales Acadamiae Medicae Silesiensis 2005, 59 (6), s. 511-514.

${ }^{5}$ M. Kutzner-Kozińska, Korekcja wad postawy, Warszawa 1986.

${ }^{6} \mathrm{M}$. Hadała i in., Wady postawy i boczne skrzywienia kręgostupa w populacji dzieci klas szóstych szkót podstawowych na terenie miasta Rzeszowa, Fizjoterapia Polska, 2006, 6 (3), s. 233-237; W. Hagner i in., Częstość występowania wad postawy u dzieci 10-13-letnich w regionie mtawskim, Kwartalnik Ortopedyczny, 2011, 1, s. 24-30.

7 R. Janiszewska i in., Nieprawidłowości postawy ciała u dzieci 6-12-letnich - uczniów szkót podstawowych z Radomia - badania pilotażowe, Problemy Higieny i Epidemiologii, 2009, 90 (3), s. 342346; E. Sokołowska, H. Krakowiak, Częstość występowania wad postawy ciała u młodzieży z Gimnazjum i Liceum plastycznego w Bydgoszczy, Medical and Biological Scinces, 2007, 21, 3, s. 83-85. 
Kratěnová i współautorzy ${ }^{8}$ podają, że u naszych południowych sąsiadów zaledwie u 38,3\% uczniów w wieku 7-15 lat zdiagnozowano wady postawy.

Nabyte wady postawy, a z takimi mamy do czynienia najczęściej, są efektem dwóch głównie zjawisk. Pierwszym jest złe odżywianie, natomiast drugim oddziaływanie na organizm całej gamy czynników środowiskowych, z których największy wpływ na kształtowanie niewłaściwej postawy ma ograniczenie, a w skrajnych przypadkach prawie całkowita redukcja aktywności fizycznej. Rozpatrując problem w aspekcie dietetycznym, należy zwrócić uwagę na dwie skrajne sytuacje. W krajach ubogich ilość i jakość pokarmów nie zaspokaja $\mathrm{w}$ pełni zapotrzebowania organizmów dzieci i młodzieży na białko czy inne elementy stanowiące materiał budulcowy kości (wapń) czy mięśni. W państwach bogatych natomiast, nadmiar żywności wysoko przetworzonej powoduje, że ilość dostarczanych pokarmów wysokoenergetycznych znacznie przekracza zapotrzebowanie na nie organizmu. Prowadzi to wielokrotnie do nadmiernej otyłości bądź otłuszczenia, a co za tym idzie - do występowania wad postawy. Jeżeli chodzi o czynniki środowiskowe zagrażające utrzymywaniu prawidłowej postawy ciała, to najważniejszym jest znaczne ograniczenie aktywności ruchowej dzieci i młodzieży. Obserwowane powszechnie zachowania sedenteryjne są spowodowane długotrwałym przebywaniem przed ekranem telewizora lub komputera. Z badań przeprowadzonych przez Instytut Matki i Dziecka w ramach HBSC $^{9}$ wynika, że 41,1\% uczniów w wieku 11-12 lat, 42,3\% uczniów w wieku 13-14 lat i aż 45\% uczniów w wieku 15-16 lat przeznacza $\mathrm{w}$ dniach nauki szkolnej na oglądanie telewizji (w tym wideo i DVD) od 2 do 3 godzin. Na podobny przedział czasu (2-3 godziny dziennie) spędzony przy komputerze (Internet, czat, odrabianie lekcji) wskazało 32,0\% dla dzieci 11-12-letnich, 33,7\% dla 13-14-latków i 32,6\% dla 15-16-latków. Dodatkowe 2-3 godziny dziennie badani poświęcają na gry komputerowe lub na konsoli. Taki przedział deklaruje aż 29,1\% uczniów 11-12-letnich, 26,2\% uczniów 13-14-letnich i 25,1\% uczniów 15-16-letnich. Nienaturalna, a przede wszystkim zbyt długa pozycja siedząca powoduje garbienie się, osłabienie mięśni oraz inne deformacje górnej części tułowia. Innym niebezpieczeństwem dla kształtowania się prawidłowych krzywizn kręgosłupa może być także przeciążony tornister szkolny ${ }^{10}$.

8 J. Kratěnová et al., Prevalence and Risk Factors of Poor Posture in School Children in the Czech Republic, Journal of School Health, March 2007, 77, 3, s. 131-137.

${ }^{9}$ J. Mazur, A. Małkowska-Szkutnik, Wyniki badań HBSC, Raport techniczny, Warszawa 2011.

10 Y. Hong, Cheung Chi-Kin, Gait and posture responses to backpack load during level walking in children, Gait and Posture, 2003, 17, s. 28-33. 
Najskuteczniejszym sposobem zapobiegania powstawaniu różnego rodzaju zaburzeń prawidłowej postawy ciała jest oczywiście profilaktyka. Rosnąca jednak lawinowo liczba zdiagnozowanych przypadków wad postawy wymaga podejmowania określonych działań poprawiających istniejącą sytuację. Najbardziej skutecznym sposobem tej poprawy jest jak najszerszy udział dzieci i młodzieży ze stwierdzonymi wadami postawy w różnorodnych formach gimnastyki korekcyjnej. Niestety, na podstawie $\$ 28$ pkt. 2. Zarządzenia nr 52 DSOZ Prezesa Narodowego Funduszu Zdrowia z 2008 roku „fundusz nie finansuje gimnastyki korekcyjno-kompensacyjnej (grupowej i indywidualnej)", co w przypadku rodzin o niskich dochodach znacznie ogranicza możliwość korzystania z takiej formy ćwiczeń. Zajęcia z gimnastyki korekcyjnej, w myśl nowych wytycznych oświatowych, leżą w gestii dyrektora szkoły. Mogą się odbywać w ramach tzw. godzin do dyspozycji dyrektora. $\mathrm{W}$ takiej formule, konkurują one $\mathrm{z}$ pozalekcyjnymi zajęciami muzycznymi, plastycznymi, czy teatralnymi, a w związku z tym mogą zostać ograniczone do minimum lub nie odbywać się wcale. Kiedy jednak się odbywają, dzieci pracują w grupie, w której mamy do czynienia z różnymi typami wad - czasami całkowicie przeciwstawnymi. Indywidualizacja ćwiczeń, a w szczególności dostrzeżenie i wyegzekwowanie poprawności wykonania poszczególnych elementów przez osobę prowadzącą jest wówczas znacznie utrudnione. Niełatwo również śledzić zaaplikowaną liczbę powtórzeń danego ćwiczenia u każdego dziecka. Dodatkowo, prowadząc korektywę grupową, w trakcie pełnej jednostki lekcyjnej (45 minut), dzieci szczególnie młodsze szybko się męczą lub ich zborność ruchowa nie pozwala na wykonanie lub zapamiętanie techniki wykonania zadanego ruchu.

Rodzice dzieci zakwalifikowanych do ćwiczeń korygujących określone deformacje postawy ciała muszą być świadomi, że powodzenie kilkuletniego procesu korekty wady dziecka wymaga dużej częstotliwości, a przede wszystkim systematyczności ćwiczeń. Wielu autorów właśnie w systematyczności ćwiczeń upatruje źródeł powodzenia procesu korekcji. M. Kotecka-Noceń i H. Płukarz podkreślają, że „(...) prowadzenie zabiegów korygujących wady stóp dwa razy w tygodniu przez doskonałego fachowca nie zastąpi ćwiczeń, jakie można (...) przeprowadzać codziennie w domu"11. Podobnie zjawisko oceniają Renz-Polster, Menche i Schäffler, pisząc, że "(..) ćwiczenie dwa razy w tygodniu po pół godziny z pewnością nie odniesie pożądanego skutku"12. Program tych ćwiczeń musi ulegać również pewnym modyfikacjom, uzależnionym od stopnia korekcji wady. Fizjoterapeuta

11 M. Kotecka-Noceń, H. Płukarz, Stopy płaskie u dzieci. Gimnastyka lecznicza, Warszawa 1975.

${ }^{12}$ H. Renz-Polster, N. Menche, A. Scheffler, Encyklopedia zdrowia dziecka, Poznań 2008. 
prowadzący zajęcia gimnastyki korekcyjnej nie odniesie sukcesu, jeżeli motywacja ćwiczących będzie niewielka. Rzeczą niezwykle trudną jest wzbudzenie takiej motywacji u kilku- czy kilkunastoletnich dzieci. Badania Fitzgeralda i współautorów ${ }^{13}$ dowodzą, że poziom motywacji osób biorących udział w ćwiczeniach rehabilitacyjnych znacznie wzrasta, kiedy jako jedną $\mathrm{z}$ form terapii wykorzystuje się interaktywne gry ruchowe.

\section{Zastosowanie nowoczesnych technologii (Human Body Tracking) $w$ interaktywnych grach ruchowych - nowej formie ćwiczeń korygujących wady postawy}

Znaczącym impulsem motywacyjnym, zwiększającym chęć i zaangażowanie dziecka $\mathrm{w}$ ćwiczeniach, może być udział w interaktywnej grze ruchowej. Jej treść i fabuła, wymuszająca i korygująca określone formy ruchu, muszą odpowiadać aktualnym możliwościom percepcyjnym dziecka. Odpowiednio dobrane elementy ruchowe winny być precyzyjnie dostosowane do rodzaju korygowanej wady. Ważne, aby ćwiczenia wzmacniające określone mięśnie czy grupy mięśniowe były przeplatane ćwiczeniami rozluźniającymi i relaksacyjnymi. Gra nie może trwać zbyt długo, ze względu na stopień zmęczenia, oraz przebiegać w zbyt szybkim tempie, co może wpływać na dokładność wykonania elementów ruchowych. Najistotniejszym warunkiem powodzenia wykorzystania interaktywnych gier ruchowych w korekcji wad postawy będzie to, czy potrafią one zaciekawić i wciągnąć dziecko, a także jaką popularnością będą cieszyły się w jego najbliższym środowisku, grupie rówieśniczej itp. Obecne możliwości techniczne stwarzają taką szansę.

Gwałtowny rozwój nowych technologii skutkuje pojawieniem się w powszechnym użyciu urządzeń, których jednym z wielu możliwych zastosowań jest detekcja i rejestracja naturalnych ruchów człowieka. Teletransmisja tych danych w czasie rzeczywistym daje możliwość kontroli zachowań motorycznych i ich ewentualnej modyfikacji, jak również dostosowania do indywidualnych potrzeb ćwiczącego.

Obecnie istnieją dwa główne systemy rejestrujące i przetwarzające na trójwymiarową animację komputerową różnorodne formy aktywności fizycznej człowieka (Human Body Tracking). Do tego celu wykorzystuje się

${ }^{13}$ D. Fitzgerald et al., Effects of a Wobble Board-Based Therapeutic Exergaming System for Balance Training on Dynamic Postural Stability and Intrinsic Motivation Levels, Journal of Orthopaedic \& Sports Physical Therapy, 2010, 40, 1, s. 11-19. 
zsynchronizowany system kamer lub połączone moduły czujników inercyjnych, akcelerometrów i goniometrów. W pierwszym z tych systemów stosuje się kilka lub kilkanaście kamer emitujących podczerwień o bardzo dużej szybkości i wysokiej rozdzielczości ustawionych tak, aby mogły rejestrować trójwymiarowy obraz poruszającego się człowieka na ściśle oznaczonej i przygotowanej powierzchni - scenie (ryc. 1). Poruszająca się na scenie osoba zakłada specjalny obcisły kostium, z reguły czarny lub ciemny, na którym umieszczane są markery. Zasada działania systemu (motion capture system mocap) opiera się na metodzie analizy ruchów poruszającej się postaci i przeniesienia ich do komputera celem dalszej animacji.

System stwarza możliwość uchwycenia trójwymiarowego obrazu aktualnej pozycji ciała, zapisaniu ich $\mathrm{w}$ czasie rzeczywistym przez komputer, $\mathrm{z}$ jednoczesną transformacją tego obrazu na dowolną animację komputerową. Dzięki niemu zarejestrowany ruch postaci jest naturalny i realistyczny, a przechwycone dane gotowe do dalszej obróbki. Stworzenie animacji lub innej transformacji graficznej z wykorzystaniem tej techniki wymaga oprócz zestawu kamer zastosowania tzw. markerów. Znaczniki umieszcza się $\mathrm{w}$ odpowiedzialnych za ruch punktach antropometrycznych (głównie w miejscach połączeń stawowych).

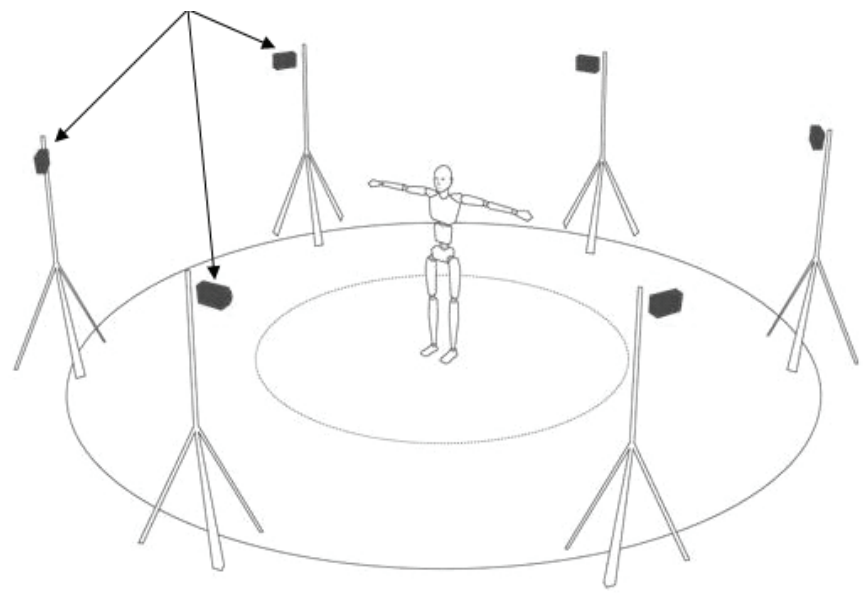

Ryc. 1. Przykład lokalizacji 6 kamer przechwytujących ruch postaci na wyznaczonej "Scenie"

(źródło: F. Moiz; W. Leon-Salas, D.Y. Lee, Motion Tracking for Smart Home Care, Columbia MO 2010)

Ich liczba i lokalizacja uzależniona jest od typu budowy ciała - szczególnie wzrostu. W większości obecnie wykorzystywanych systemów stosuje się 
przypinane, za pomocą taśm rzepowych, znaczniki odblaskowe. Obecnie jednak coraz częściej stosuje się markery emitujące światło $\mathrm{w}$ postaci diod LED (light-emitting diodes). Wyznaczenie pozycji markera uwarunkowane jest jednoczesnym uchwyceniem go przez co najmniej 2 kamery. Rejestrują one, odizolowane filtrem optycznym od światła widzialnego, odbite światło podczerwone. Jak podkreślają jednak Raskar i współautorzy ${ }^{14}$, Pięciak i Pawłowski ${ }^{15}$, zastosowanie identycznych dla wszystkich oznaczonych punktów znaczników powoduje, że ich selekcja w jednostce czasu jest znacznie utrudniona. Dodatkowo, istotną wadą tego rozwiązania jest zastosowanie połączeń przewodowych powodujących pewne ograniczenia w wykonaniu swobodnego ruchu niektórych części ciała.

Celem wyeliminowania tych niedogodności coraz powszechniej wykorzystuje się markery aktywne, które same emitują światło. Dla jednoznacznej identyfikacji pozycji poszczególnych części ciała, pojedyncze czujniki stanowią źródła światła pulsującego $\mathrm{z}$ wysoką częstotliwością. Zastosowanie przesunięcia fazowego powoduje, że $w$ określonej jednostce czasu podczerwień emitowana jest wyłącznie przez jeden sensor ${ }^{16}$. Innym sposobem uporządkowania sekwencji sygnałów z poszczególnych czujników jest ich amplitudowa modulacja. Jej efektem jest przekazanie informacji o zmienionym natężeniu światła podczerwonego emitowanego przez dany sensor. Zastosowanie markerów niesie jednak ze sobą ryzyko wystąpienia pewnych błędów w rejestracji ruchu, wynikających z możliwości niewielkich przesunięć czujników związanych $\mathrm{z}$ ich niedostatecznym ustabilizowaniem na ciele. Inny potencjalny błąd odczytu może być skutkiem całościowego lub częściowego przesłonięcia markera, wynikającego z ruchu kończyny lub będącego wynikiem skrętu lub obrotu ciała ${ }^{17}$. Przedstawione niedogodności niwelowane są wskutek wykorzystania w układach sensorów magnetycznych lub czujników bazujących na układach inercyjnych masa - sprężyna. Dzięki możliwości identyfikacji przyspieszenia można różnicować również siłę, z jaką wykonywany jest rejestrowany ruch.

Ograniczenia wynikające $\mathrm{z}$ zastosowania $\mathrm{w}$ systemach wizualizacji ruchu (mocap) różnego rodzaju markerów spowodowały, że obecnie testowane są zupełnie nowe systemy optyczne, nie wymagające stosowania jakichkolwiek czujników. Bezmarkerowy system wizualizacji ruchu (Markerless Performance Capture) nie wymaga od użytkownika stosowania specjalnego ko-

14 R. Raskar et al., Lighting-aware motion capture using photosensing markers and multiplexed illuminators, ACM Transactions on Graphics, 2007, 26, 3.

15 T. Pięciak, R. Pawłowski, Wizualizacja ruchu człowieka, Kraków 2009.

16 Tamże.

17 Tamże. 
stiumu, ani wykorzystywania jakichkolwiek czujników. Całość poruszającej się postaci dzieli się na segmenty, które są śledzone przez obiektyw kamery niezależnie. Zarejestrowany kamerą (kamerami) ruch jest przetwarzany z wykorzystaniem odpowiednio dobranych algorytmów segmentacji obrazu. System ten może być wykorzystywany również do śledzenia ruchów kilku lub wielu ćwiczących równocześnie (markerless multi-person motion capture). Jego zasadniczym walorem jest możliwość segmentacji rejestrowanego kamerami obrazu i przyporządkowanie każdego piksela wyłącznie jednej ćwiczącej osobie ${ }^{18}$. Jak sugerują Corazza i współautorzy ${ }^{19}$, dokładność bezmarkerowych systemów wizualizacji ruchu, przy zapewnieniu określonych warunków rejestracji (odpowiednia liczba kamer, właściwe oświetlenie), jest porównywalna ze stosowaniem tradycyjnych metod z wykorzystaniem czujników. Hasler i współautorzy ${ }^{20}$ oraz Sheets ${ }^{21}$ testowali bezmarkerowe systemy wizualizacji w naturalnym środowisku plenerowym. Jak podkreśla A. Sheets,

potencjalne możliwości zastosowania bezmarkerowych systemów wizualizacji w medycynie są olbrzymie, ponieważ można za ich pośrednictwem kwantyfikować ruch człowieka bez konieczności umieszczania na ciele czujników lub jakiegokolwiek innego sprzętu ograniczającego swobodny ruch. Ludzie mogą poruszać się naturalnie $\mathrm{w}$ dowolnym środowisku nie ograniczając się jedynie do laboratorium ${ }^{22}$.

Wydaje się, że zastosowanie tego wariantu technicznego w interaktywnych grach ruchowych, szczególnie w przypadku młodszych dzieci, wydaje się rozwiązaniem bardzo obiecującym.

Nieco inny system rejestracji ruchów ciała z użyciem kamer w plenerze zaprezentowali Shiratori i współautorzy23. Wykorzystali w swoim projekcie 15 kamer zewnętrznych, zamocowanych na tułowiu za pomocą taśm rzepowych typu Velcro (ryc. 2).

${ }^{18}$ L. Yebin et al., Markerless motion capture of interacting characters using multi-view image segmentation, Computer Vision and Pattern Recognition, IEEE Conference (CYPR), 2011.

$19 \mathrm{~S}$. Corazza et al., Automatic generation of a subject-specific model for accurate markerless motion capture and biomechanical applications, IEEE Transactions on Biomedical Engineering, 2010, 57,4 , s. 806-812.

${ }^{20}$ N. Hasler et al., Markerless motion capture with unsynchronized moving cameras, In Proc. IEEE Computer Society Conference on Computer Vision and Pattern Recognition, 2009, s. 224231.

${ }^{21}$ A. Sheets, Markerless Motion Capture Offers A New Angle on Tennis Injuries, The Ohio State University, Columbus Ohio 2012.

22 Tamże.

23 T. Shiratori et al., Motion Capture from Body-Mounted Cameras, ACM Transactions on Graphics, 2011, 30, 4, Proc. ACM SIGGRAPH. 


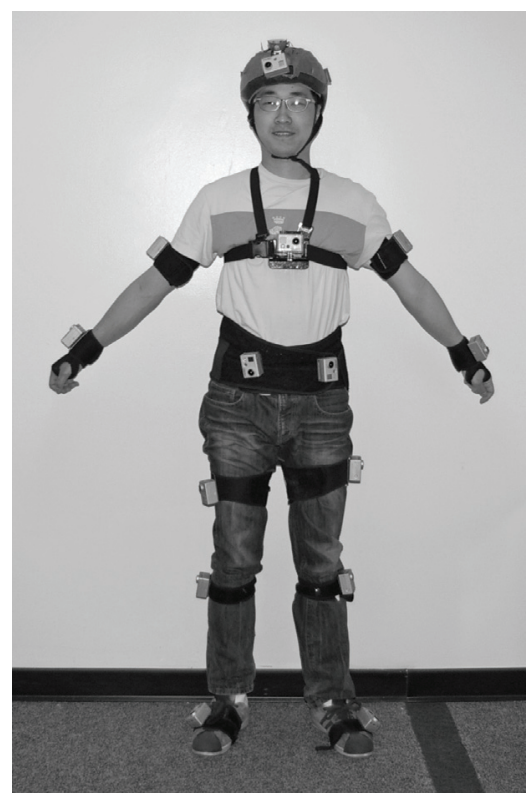

Ryc. 2. Umiejscowienie kamer zewnętrznych do rejestracji swobodnego ruchu w plenerze (źródło: T. Shiratori et al., Motion Capture from Body-Mounted Cameras, ACM Transactions on Graphics, 2011, 30, 4. Proc. ACM SIGGRAPH)

Jakość rekonstrukcji rejestrowanego ruchu autorzy porównali z wynikami uzyskiwanymi w dostępnych na rynku optycznych systemach wizualizacji. Rezultaty badań wykazały, że kamery zewnętrzne znacznie dokładniej odwzorowywały naturalny ruch ciała. Dodatkowym walorem tego systemu jest jego znacznie niższa cena, w porównaniu z klasycznymi systemami wizualizacji.

Alternatywę dla optycznego sposobu wizualizacji ruchu człowieka z wykorzystaniem kamer stanowi zintegrowany modułowy system czujników inercyjnych (inertial motion capture technology) typu MTx (Xsens Techologies BV) (Schepers, Roetenberg, Veltink 2010). Te małe (38 × $53 \times 21 \mathrm{~mm})$, lekkie (waga nie przekracza 30 g) i wytrzymałe sensory składają się z trójosiowych akcelerometrów, magnetometrów i żyroskopów (ryc. 3). Akcelerometr mierzy siły potrzebne do pokonania grawitacji (odchylenia w pionie), magnetometr - ruchy segmentów ciała w stosunku do wyznaczonego kierunku północnego (odchylenia w poziomie), a żyroskop - prędkość kątową i szybkość obrotu czujnika24. Zestaw rejestrujący składa się z kompletu

24 P. Bonato, Wearable sensors/systems and their impact on biomedical engineering, IEEE Engineering in Medicine and Biology Magazine, 2003, 22, 3, s. 18-20; B. O'Huiginn et al., Therapeutic 


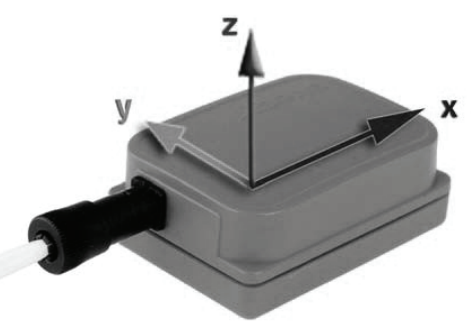

Ryc. 3. Inercyjny czujnik ruchu typu MTx

(źródło: B. O'Huiginn et al., Therapeutic Exergaming, [w:] Sixth International Workshop on Wearable and Implantable Body Sensor Networks, BSN, red. B. Lo, P. Mitcheson, IEEE Computer Society 2009)

17 czujników inercyjnych oraz urządzenia synchronizującego. Czujniki umieszczone są na stopach, podudziach, udach, podbrzuszu, mostku, głowie, w okolicy kąta wyrostków barkowych (angulus acromii), ramionach, przedramionach i dłoniach.

Każdy z modułowych sensorów połączony jest z urządzeniem sterującym tzw. Xbus Masters, które umieszcza się na plecach. Urządzenie sterujące synchronizuje pracę wszystkich czujników i przekazuje dane poprzez port USB do komputera generującego odpowiednią animację gry. Lokalizację czujników przedstawiono na rycinie 4.

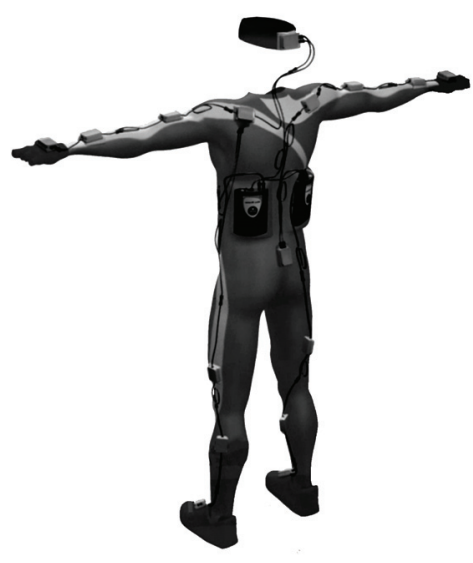

Ryc. 4. Lokalizacja czujników ruchu typu MTx oraz urządzenia sterującego Xbus Masters (źródło: D. Roetenberg, H. Luinge, P. Slycke, Xsens MVN: Full 6DOF Human Motion Tracking Using Miniature Inertial Sensors, Xsens Technologies B.V. Enschede 2009 s. 1)

Exergaming, [w:] Sixth International Workshop on Wearable and Implantable Body Sensor Networks, BSN. IEEE Computer Society, red. B. Lo, P. Mitcheson, Berkeley CA 2009. 
W celu łatwego i szybkiego zakładania wykonanego z lycry kostiumu, zarówno czujniki, ich połączenia, jak i urządzenie sterujące są z nim zintegrowane. Całkowita waga kostiumu, łącznie z zestawem 17 czujników, urządzeniem sterującym i baterią, nie przekracza 2 kilogramów ${ }^{25}$. Zarejestrowany rzeczywisty obraz postaci (ryc. 5a) może być transformowany w zależności od fabuły gry jako forma studyjna (ryc. 5b) lub przedstawiony jako animacja (ryc. 5c).

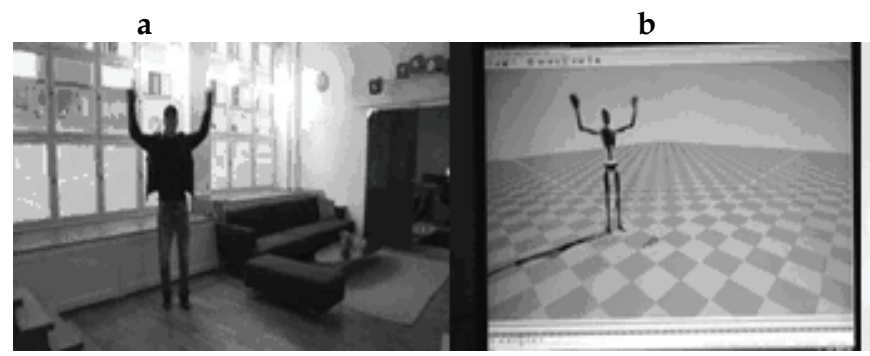

c

Ryc. 5. Możliwości komputerowej transformacji rzeczywistego obrazu postaci w zależności od potrzeb jego wykorzystania w grze

(źródło: D. Roetenberg, H. Luinge, P. Slycke, Xsens MVN, s. 2)

Jednym z ciekawszych rozwiązań technicznych, które może znaleźć zastosowanie $\mathrm{w}$ interaktywnych grach ruchowych, ukierunkowanych na poprawę funkcjonowania mięśni posturalnych, jest zaprezentowana przez Fitzgeralda i współautorów ${ }^{26}$ ruchoma platforma do ćwiczeń równoważnych (ryc. 6A i B). Równocześnie z prezentacją potencjalnych możliwości zastosowania tego urządzenia $\mathrm{w}$ rehabilitacji ruchowej, autorzy przedstawili również dane wskazujące na znaczący wzrost motywacji ćwiczących wykorzystujących urządzenie $\mathrm{w}$ porównaniu $\mathrm{z}$ osobami stosującymi tradycyjne formy ćwiczeń.

Nowoczesne technologie wizualizacji ruchu wykorzystywane są obecnie $\mathrm{w}$ trzech typach wiodących na rynku konsoli do gier Nintendo Wii, Sony Playstation Move oraz Xbox Kinect. Działanie Nintendo Wii i Sony Playstation Move opiera się na śledzeniu przez kamerę aktualnego położenia zainstalowanych na ciele inercyjnych czujników ruchu, natomiast w konsoli Xbox Kinect - na skanowaniu za pomocą wiązki podczerwieni swobodnych ruchów ciała. Trudno obecnie stwierdzić, który z tych systemów byłby $\mathrm{z}$ praktycznego punktu widzenia najlepszym rozwiązaniem $\mathrm{w}$ przypadku

25 D. Roetenberg, H. Luinge, P. Slycke, Xsens MVN: Full 6DOF Human Motion Tracking Using Miniature Inertial Sensors, Xsens Technologies B.V. Enschede 2009.

26 D. Fitzgerald et al., Effects of a Wobble Board-Based Therapeutic Exergaming System, s. 11-19. 
interaktywnych gier ruchowych ukierunkowanych na korekcję wad postawy. Bergmann i McGregor ${ }^{27}$ podkreślają, że obecnie jest jeszcze zbyt mało dostępnych danych dotyczących dokładności odwzorowania przez te systemy poszczególnych ruchów oraz preferencji użytkowników tego sprzętu. Jak sugeruje jednak Bonato 28 , informacje odnośnie określonych faz ruchu z wykorzystaniem mocowanych na ciele czujników mogą być szeroko wykorzystane $\mathrm{w}$ praktyce rehabilitacyjnej lub medycznej.

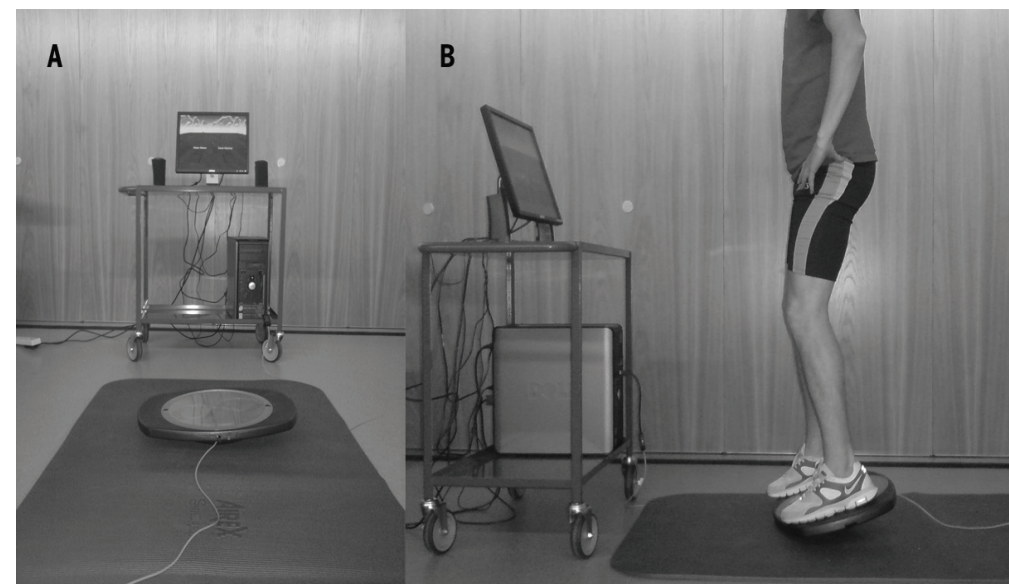

Ryc. 6. Ruchoma platforma do ćwiczeń równoważnych

(źródło: D. Fitzgerald et al., Effects of a Wobble Board-Based Therapeutic Exergaming System for Balance Training on Dynamic Postural Stability and Intrinsic Motivation Levels, Journal of Orthopaedic \& Sports Physical Therapy, 2010, 40, s. 11-19)

\section{Podsumowanie}

Lawinowo rosnąca $w$ naszym kraju liczba dzieci i młodzieży w okresie adolescencji ze zdiagnozowanymi wadami postawy stanowi jeden $\mathrm{z}$ najpoważniejszych problemów zdrowotnych współczesnego społeczeństwa. Przedstawione przykłady różnorodnych metod rejestracji i przetwarzania ruchu w czasie rzeczywistym mogą stać się doskonałym narzędziem wspomagającym stosowane obecnie tradycyjne formy korekcji wad postawy. Znaczny wzrost popularności interaktywnych gier ruchowych wśród dzieci i młodzieży, w porównaniu z tradycyjnymi, stacjonarnymi grami kompute-

27 J.H.M. Bergmann, A.H. McGregor, Body-Worn Sensor Design: What Do Patients and Clinicians Want? Annals of Biomedical Engineering, 2011, 39, 9.

${ }_{28} \mathrm{P}$. Bonato, Wearable sensors/systems and their impact on biomedical engineering, IEEE Engineering in Medicine and Biology Magazine, 2003, 22, 3, s. 18-20. 
rowymi, stwarza możliwości ich wykorzystania również w obszarze korekcji wad postawy. Stworzenie wciągającej, ciekawej graficznie i atrakcyjnej formy ćwiczeń może stać się źródłem przełamywania stereotypów zachowań sedenteryjnych, a interaktywne formy gier powinny stanowić inspiracje ruchową pobudzającą do zwiększenia dziennej dawki aktywności fizycznej. Dodatkowo, ich atrakcyjność w naturalny sposób wpłynie na systematyczność aplikowanych ćwiczeń - jeden z podstawowych warunków powodzenia procesu korekcji wad posturalnych.

\section{BIBLIOGRAFIA}

Bergmann J.H.M., McGregor A.H., Body-Worn Sensor Design: What Do Patients and Clinicians Want? Annals of Biomedical Engineering, 2011, 39, 9.

Bonato P., Wearable sensors/systems and their impact on biomedical engineering, IEEE Engineering in Medicine and Biology Magazine, 2003, 22, 3.

Corazza S., Gambaretto E., Mündermann L., Andriacchi T., Automatic generation of a subject-specific model for accurate markerless motion capture and biomechanical applications, IEEE Transactions on Biomedical Engineering, 2010, 57, 4.

Czernicki K., Dumała J., Jędrzejek H., Wawrzyczek J., Częstość występowania wad postawy u dzieci w wieku 4-5 lat uczeszzzajacych do przedszkoli w Mystowicach, Annales Acadamiae Medicae Silesiensis 2005, 59 (6).

Fitzgerald D., Trakarnratanakul N., Smith B., Caulfield B., Effects of a Wobble Board-Based Therapeutic Exergaming System for Balance Training on Dynamic Postural Stability and Intrinsic Motivation Levels, Journal of Orthopaedic \& Sports Physical Therapy 2010, 40, 1.

Hadała M., Bieganowski K., Sołek D., Rzuciło K., Jachym Ł., Snela S., Wady postawy i boczne skrzywienia kręgostupa w populacji dzieci klas szóstych szkót podstawowych na terenie miasta Rzeszowa, Fizjoterapia Polska, 2006, 6 (3).

Hagner W., Bąk D., Lulińska-Kuklik E., Hagner-Derengowska M., Częstość występowania wad postawy u dzieci 10-13-letnich w regionie mławskim, Kwartalnik Ortopedyczny, $2011,1$.

Hasler N., Rosenhahn B., Thormahlen T., Wand M., Gall J., Seidel H.-P. Markerless motion capture with unsynchronized moving cameras, In Proc. IEEE Computer Society Conference on Computer Vision and Pattern Recognition, 2009.

Hong Y., Chi-Kin Cheung, Gait and posture responses to backpack load during level walking in children, Gait and Posture, 2003, 17.

Janiszewska R., Tuzinek S., Nowak S., Ratyńska A., Biniaszewski T., Nieprawidtowości postawy ciała u dzieci 6-12-letnich - uczniów szkót podstawowych z Radomia - badania pilotażowe, Problemy Higieny i Epidemiologii, 2009, 90 (3).

Kasperczyk T., Wady postawy ciała. Diagnostyka i leczenie, Wydawnictwo „Kasper”, Kraków 1994.

Kotecka-Noceń M., Płukarz H., Stopy płaskie u dzieci. Gimnastyka lecznicza, PZWL, Warszawa 1975.

Kratěnová J., Žejglicová K., Malý M., Filipová V., Prevalence and Risk Factors of Poor Posture in School Children in the Czech Republic, Journal of School Health, March 2007, 77, 3. 
Kutzner-Kozińska M., Korekcja wad postawy, Wyd. 2, Wydawnictwo Szkolne i Pedagogiczne, Warszawa 1986.

Leusmann P., Mollering Ch., Klack L., Kasugai K., Ziefle M., Rumpe B., Your Floor Knows Where You Are: Sensing and Acquisition of Movement Data, MDM '11 Proceedings of the IEEE 12th International Conference on Mobile Data Management, 2011, 2.

Maciałczyk-Paprocka K., Krzyżaniak A., Kotwicki T., Kałużny Ł., Przybylski J., Postawa ciała dzieci w wieku przedszkolnym, Problemy Higieny i Epidemiologii, 2011, 92 (2).

Mazur J., Małkowska-Szkutnik A., Wyniki badań HBSC, Raport techniczny, Warszawa 2011.

Moiz F., Leon-Salas W.D., Lee Y., Motion Tracking for Smart Home Care, Missouri Regional Life Sciences Summit, Mospace, University of Missouri Columbia MO 2010.

O'Huiginn B., Smyth B., Coughlan G., Fitzgerald D., Caulfield B., Therapeutic Exergaming, [w:] Sixth International Workshop on Wearable and Implantable Body Sensor Networks, BSN. IEEE Computer Society, red. B. Lo, P. Mitcheson, Berkeley CA 2009.

Pięciak T., Pawłowski R., Wizualizacja ruchu człowieka, AGH, Kraków 2009.

Raskar R., Nii H., De Decker B., Hashimoto Y., Summet J., Moore D., Zhao Y., Weshues J., Dietz P., Inami M., Nayar S., Barnwell J., Noland M., Bekaert P., Branzoi V., Bruns E., Lighting-aware motion capture using photosensing markers and multiplexed illuminators, ACM Transactions on Graphics, 2007, 26, 3.

Renz-Polster H., Menche N., Scheffler A., Encyklopedia zdrowia dziecka, Media Rodzina, Poznań 2008.

Roetenberg D., Luinge H., Slycke P., Xsens MVN: Full 6DOF Human Motion Tracking Using Miniature Inertial Sensors, Xsens Technologies B.V. Enschede 2009.

Schepers H.M., Roetenberg D., Veltink P.H., Ambulatory human motion tracking by fusion of inertial and magnetic sensing with adaptive actuation, Med. Bio. Eng. Comput, 2010, 48.

Sheets A., Markerless Motion Capture Offers A New Angle on Tennis Injuries, The Ohio State University, Columbus Ohio 2012.

Shiratori T., Soo Parky H., Sigal L., Sheikhy Y., Hodgins J.K., Motion Capture from BodyMounted Cameras, ACM Transactions on Graphics, 2011, 30, 4, Proc. ACM SIGGRA$\mathrm{PH}$.

Sokołowska E., Krakowiak H., Częstość występowania wad postawy ciała u młodzieży z Gimnazjum i Liceum plastycznego w Bydgoszczy, Medical and Biological Scinces, 2007, 21, 3.

Staiano A.E., Calvert S.L., Exergames for Physical Education Courses: Physical, Social, and Cognitive Benefits, Child Development Perspectives, 2011, 5, 2.

Yebin L., Stoll C., Gall J., Seidel H.P., Theobalt C., Markerless motion capture of interacting characters using multi-view image segmentation, Computer Vision and Pattern Recognition, IEEE Conference (CYPR), 2011.

Zarządzenie Nr 52/2008/DSOZ Prezesa Narodowego Funduszu Zdrowia z 29 lipca 2008 r. w sprawie określenia warunków zawierania i realizacji umów w rodzaju rehabilitacja lecznicza, Warszawa 2008.

Zwierzchowska A., Gawlik K., Korektywa dzieci i młodzieży z dysfunkcjami wzroku lub stuchu, AWF, Katowice 2006. 